\title{
Arbuscular mycorrhizal fungi in soil aggregates from fields of "murundus" converted to agriculture
}

\author{
Marco Aurélio Carbone Carneiro(1), Dorotéia Alves Ferreira(2), Edicarlos Damacena de Souza(3), \\ Helder Barbosa Paulino ${ }^{(4)}$, Orivaldo José Saggin Junior ${ }^{(5)}$ and José Oswaldo Siqueira ${ }^{(6)}$
}

\begin{abstract}
(1)Universidade Federal de Lavras, Departamento de Ciência do Solo, Caixa Postal 3037, CEP 37200-000 Lavras, MG, Brazil. E-mail: marcocarbone@dcs.ufla.br (2)Universidade de São Paulo, Escola Superior de Agricultura Luiz de Queiroz, Departamento de Ciência do Solo, Avenida Pádua Dias, o 11, CEP 13418-900 Piracicaba, SP, Brazil. E-mail: dorotyferreira@yahoo.com.br (3)Universidade Federal de Mato Grosso, Campus de Rondonópolis, Instituto de Ciências Agrárias e Tecnológicas de Rondonópolis, Rodovia MT 270, Km 06, Sagrada Família, CEP 78735-901 Rondonópolis, MT, Brazil. E-mail: edicarlos@pq.cnpq.br (4)Universidade Federal de Goiás, Regional Jataí, BR 364, Km 192, CEP 75804-020 Jataí, GO, Brazil. E-mail: helderlino51@yahoo.com.br ${ }^{(5)}$ Embrapa Agrobiologia, BR 465, Km 7, CEP 23891-000 Seropédica, RJ, Brazil. E-mail: orivaldo.saggin@embrapa.br ${ }^{(6)}$ Instituto Tecnológico Vale, Rua Boaventura da Silva, № 955, CEP 66055-090 Belém, PA, Brazil. E-mail: jose.oswaldo.siqueira@itv.org
\end{abstract}

Abstract - The objective of this work was to evaluate the spore density and diversity of arbuscular mycorrhizal fungi (AMF) in soil aggregates from fields of "murundus" (large mounds of soil) in areas converted and not converted to agriculture. The experiment was conducted in a completely randomized design with five replicates, in a $5 \times 3$ factorial arrangement: five areas and three aggregate classes (macro-, meso-, and microaggregates). The evaluated variables were: spore density and diversity of AMF, total glomalin, total organic carbon (TOC), total extraradical mycelium (TEM), and geometric mean diameter (GMD) of soil aggregates. A total of 21 AMF species was identified. Spore density varied from 29 to 606 spores per $50 \mathrm{~mL}$ of soil and was higher in microaggregates and in the area with 6 years of conversion to agriculture. Total glomalin was higher between murundus in all studied aggregate classes. The area with 6 years showed lower concentration of TOC in macroaggregates $\left(8.6 \mathrm{~g} \mathrm{~kg}^{-1}\right)$ and in microaggregates $\left(10.1 \mathrm{~g} \mathrm{~kg}^{-1}\right)$. TEM was greater at the top of the murundus in all aggregate classes. GMD increased with the conversion time to agriculture. The density and diversity of arbuscular mycorrhizal spores change with the conversion of fields of murundus into agriculture.

Index terms: diversity of arbuscular mycorrhizal fungi, geometric mean diameter, total glomalin, total mycelium, total organic carbon.

\section{Fungos micorrízicos arbusculares em agregados do solo de campos de murundus convertidos em agricultura}

\begin{abstract}
Resumo - O objetivo deste trabalho foi avaliar a densidade e a diversidade de esporos de fungos micorrízicos arbusculares (FMA) nos agregados do solo de campos de murundus, em áreas convertidas e não convertidas para agricultura. O experimento foi conduzido em delineamento inteiramente casualizado com cinco repetições, em arranjo fatorial 5x3: cinco áreas e três classes de agregados (macro, meso e microagregados). As variáveis avaliadas foram: densidade e diversidade de esporos de FMA, glomalina total, carbono orgânico total (COT), micélio extrarradicular total (MET) e diâmetro médio geométrico (DMG) dos agregados do solo. Foram identificadas 21 espécies de FMA. A densidade de esporos variou de 29 a 606 por $50 \mathrm{~mL}$ de solo e foi maior nos microagregados e na área com 6 anos de conversão para agricultura. A glomalina total foi maior entre os murundus em todas as classes de agregados em estudo. A área com 6 anos apresentou menor concentração de COT nos macroagregados $\left(8,6 \mathrm{~g} \mathrm{~kg}^{-1}\right)$ e nos microagregados $\left(10,1 \mathrm{~g} \mathrm{~kg}^{-1}\right)$. O MET foi maior no topo dos murundus em todas as classes de agregados. O DMG aumentou com o tempo de conversão para agricultura. A densidade e a diversidade de esporos de fungos micorrízicos arbusculares mudam com a conversão dos campos de murrundus em agricultura.
\end{abstract}

Termos para indexação: diversidade de fungos micorrízicos arbusculares, diâmetro médio geométrico, glomalina total, micélio total, carbono orgânico total.

\section{Introduction}

Soils present a three-dimensional arrangement of organomineral complexes, called aggregates, which influence its physical, chemical, and biological attributes, and are one of the crucial factors for maintaining the sustainability of ecosystems (Tisdall $\&$ Oades, 1982). Among the microorganisms that aid 
in the formation and maintenance of soil aggregates, arbuscular mycorrhizal fungi (AMF) have a key role (Miller \& Jastrow, 2000). Through their network of mycelia, AMF physically and chemically unite soil components forming organomineral aggregates, respectively, by forcing the particles together and by releasing compounds with cementing action, such as glomalin (Rillig \& Mummey, 2006), promoting soil structure stabilization. AMF belong to the phylum Glomeromycota (Schuessler, 2013) and produce large amounts of hyphae in soil, having a greater involvement in the formation and particularly in the stabilization of macroaggregates $(>250 \mu \mathrm{m})$ (Tisdall et al., 1997). The greater abundance of AMF in aggregates $>1 \mathrm{~mm}$ can contribute to carbon sequestration, whereas some bacteria and nematodes increase the accumulation of carbon in aggregates $<1 \mathrm{~mm}$ (Zhang et al., 2013). Studies confirm the influence of AMF in macroaggregates (Cavagnaro et al., 2006; Bedini et al., 2009), but information on the role of AMF in smaller aggregates $(<250 \mu \mathrm{m})$ are rare. Most studies related to AMF and microaggregates seek to review the role of organic matter and carbon sequestration (Zhang et al., 2013).

The role of AMF diversity in soil-system functioning has been discussed by several authors (Buscot \& Varma, 2005; Klironomos et al., 2005); however, few have evaluated the role of AMF species richness and community composition on soil aggregation (Rillig \& Mummey, 2006), especially in fragile environments, such as fields of "murundus", a phytophysiognomy of the Cerrado biome in Brazil.

These fields are characterized by the formation of circular-shaped mounds of soil, ranging from 2 to $10 \mathrm{~m}$ in diameter and up to $2 \mathrm{~m}$ in height (Rahlao et al., 2008). The soils of these fields have low water infiltration capacity, remaining flooded between the murundus during the rainy season. These areas are vegetated by species tolerant to temporary flooding, whereas the dried part of the soil (upper-third of the murundus) presents typical vegetation of the Cerrado stricto sensu, with shrubs and trees (Marimon et al., 2012). Analogous formations to the murundus are also found in Africa, Australia, and North America (Silva et al., 2010). To convert these areas to agriculture, it is necessary to build drainage channels and flatwork, removing the murundus, besides performing soil homogenization, correction, and fertilization.
However, there are no known studies on changes in soil physical, chemical, and biological attributes in this phytophysiognomy after conversion to agriculture.

The objective of this work was to evaluate the spore density and diversity of AMF in soil aggregates from fields of murundus in areas converted and not converted to agriculture.

\section{Materials and Methods}

The study area was located in the municipality of Jataí, in the state of Goiás, Brazil (1757'11"S, $52^{\circ} 04^{\prime} 45^{\prime \prime} \mathrm{W}$, at $872 \mathrm{~m}$ of altitude). The climate, according to Köppen, is $\mathrm{Cw}$, mesothermal with a dry (May to September) and rainy season (October to April). The soil of the area was classified as a Plintossolo Háplico (Haplic Plinthaquox) - 445, 25, and $530 \mathrm{~g} \mathrm{dm}^{-3}$ of clay, silt, and sand, respectively (Santos et al., 2006) -, with conditions restricting the downward movement of water and temporary flooding during 4 to 6 months, as well as the formation of plinthite about $60 \mathrm{~cm}$ deep. The experiment was carried out in a completely randomized design with five replicates, using a $5 \times 3$ factorial arrangement, representing five areas and three soil aggregate classes (macro-, meso-, and microaggregates). The evaluated areas corresponded to a field of murundus converted to agriculture at different times; in 2010 (year of sample collection), the areas had 13,10, and 6 years of conversion. Two areas without anthropic interference were taken as reference.

The area with 13 years was under human intervention since 1995. At its incorporation to agriculture, 3.0 $\mathrm{Mg} \mathrm{ha}{ }^{-1}$ dolomitic lime were applied through grading. Since 1996, there was no soil disturbance. Crop succession was performed with soybean in harvest and with corn, millet, or sorghum in the offseason. Based on soil analysis, $1.5 \mathrm{Mg} \mathrm{ha}^{-1}$ lime was applied to the soil surface layer in 2005. This area has 98 ha and the average yield was $3.4 \mathrm{Mg} \mathrm{ha}^{-1}$ for soybean and $6.0 \mathrm{Mg} \mathrm{ha}^{-1}$ for maize.

The area with 10 years has been subject to human intervention since 2000. A total of $6.0 \mathrm{Mg} \mathrm{ha}^{-1}$ dolomitic lime were incorporated using harrow, and $0.6 \mathrm{Mg} \mathrm{ha}^{-1}$ reactive phosphate $\left(33 \% \mathrm{P}_{2} \mathrm{O}_{5}\right)$ was applied. Since 2000, there was no soil disturbance and crop succession was performed with soybean at harvest and with corn, millet, or sorghum in the off- 
season. Based on soil analysis, $2.5 \mathrm{Mg} \mathrm{ha}^{-1}$ lime were applied to soil surface in 2005 and 2007. This area has 87 ha and the average yield was 3.4 for soybean and $6.0 \mathrm{Mg} \mathrm{ha}^{-1}$ for maize.

The area with 6 years was incorporated into the agricultural system in 2004. The soil was prepared with $5.0 \mathrm{Mg} \mathrm{ha}^{-1}$ dolomitic lime through disking; $0.6 \mathrm{Mg} \mathrm{ha}^{-1}$ reactive phosphate $\left(33 \% \quad \mathrm{P}_{2} \mathrm{O}_{5}\right)$; and $2.0 \mathrm{Mg} \mathrm{ha}^{-1}$ gypsum. From 2005, there was no soil disturbance, and crop succession was performed with soybean in harvest and with corn, millet, or sorghum in the off-season. Based on soil analysis, $1.5 \mathrm{Mg} \mathrm{ha}^{-1}$ lime was applied to the soil surface layer in 2006. The area has 45 ha and the average yield was $3.1 \mathrm{Mg} \mathrm{ha}^{-1}$ for soybean and $4.5 \mathrm{Mg} \mathrm{ha}^{-1}$ for maize.

The area (148 ha) of the fields of murundus that were not converted to agriculture were used as a reference and had 33 soil mounds evenly spread out. In this case, two reference areas were considered: top of the murundus and between the murundus, considering the differences in vegetation composition due to land flooding between the murundus. The top of the murundus have typical vegetation of Cerrado stricto sensu, with a high diversity of shrubs, trees, and creeping plants, besides a constant presence of termites. Between the murundus, flooding occurs for a period of 6 months during the rainy season and the predominant vegetation is of plants of the genus Syngonanthus sp. (Eriocaulaceae). The process of converting fields of murundus into agricultural areas initially consisted in burning-off native vegetation, leveling soil surface, destroying murundus with scarification/subsoiling, and leveling soil with a grid leveler. To avoid seasonal flooding, a network of drainage channels was built, spaced at about $100 \mathrm{~m}$ and at a 0.5 to 2-m depth.

The evaluated areas are close to each other and, therefore, show similar topography, climate, and soil. The main variation between cultivated areas was the time of conversion to agriculture, forming a chronological sequence of agricultural use. Soil chemical characteristics of the studied areas are shown in Table 1.

The locations for sampling in the cultivated areas were selected using the computer program Surfer (Golden Software, Golden, CO, USA), to detect areas on a $100 \times 100-\mathrm{m}$ grid (1.0 ha polygons). Subsequently, the software selected, within each grid area, five random polygons that were considered as replicates.
In November 2010, a block of 3-kg undeformed soil (0-20 cm layer) was removed from each polygon and wrapped in plastic film, packed in coolers, and sent to the laboratory for analysis. In the laboratory, the soil of each block was broken into clods at the points of weakness, being air dried and then sieved through 7.0 and $4.0-\mathrm{mm}$ seives. The aggregate retained on the 4-mm sieve was subjected to dry sieving. For this, $100-\mathrm{g}$ aggregates $(>4.0 \mathrm{~mm})$ were placed in a set of sieves of $2.00,0.25$, and $0.053 \mathrm{~mm}$ coupled to a vibrating mechanical stirrer, and stirred for 1 $\min$ at the rate of $30 \%$ of the maximum power. After this procedure, the aggregates were classified into macroaggregates $(>2.00 \mathrm{~mm})$, mesoaggregates $(2.00$ to $0.25 \mathrm{~mm})$, and microaggregates $(0.25$ to $0.053 \mathrm{~mm})$ (Kemper \& Chepil, 1965).

In each aggregate class, the spore density and diversity of AMF were determined. To determine the spore density of mycorrhizal fungi in each class of aggregates, 50-g aggregates were stirred in a blender with water for $30 \mathrm{~s}$. Then, the liquid phase was poured into a set of sieves $(0.25 \mathrm{~mm}$ and 0.053$)$, and spores were separated by wet sieving (Gerdemann \& Nicolson, 1963) and counted using a stereoscopic microscope. The species of the AMF community were identified by the traits spore wall, color, and size, according to Schuessler (2013), mounted on microscope blades in polivinilactoglicerol (PVLG) and PVLG + Melzer's reagent $(1: 1)$.

To quantify total glomalin, $1.0 \mathrm{~g}$ of each type of aggregate, in which the extraction was performed, was used with $8.0 \mathrm{~mL}$ of $50 \mathrm{mmol} \mathrm{L}^{-1}$ sodium citrate at $\mathrm{pH}$ 8.0 over three cycles of autoclaving at $121^{\circ} \mathrm{C}$, for 1 hour per cycle. The extractor was separated from the soil via

Table 1. Soil chemical attributes in fields of murundus (mounds of soil) converted ${ }^{(1)}$ and not converted (TM and $\mathrm{BM})^{(2)}$ to agriculture in the Cerrado biome, Brazil.

\begin{tabular}{lccccccc}
\hline Areas & $\begin{array}{c}\mathrm{pH} \\
\left(\mathrm{H}_{2} \mathrm{O}\right)\end{array}$ & $\begin{array}{c}\mathrm{Al}^{3+} \\
-------\left(\mathrm{cmol}_{\mathrm{c}} \mathrm{dm}^{-3}\right)\end{array}$ & $\begin{array}{c}\mathrm{Ca}^{2+} \\
\mathrm{Mg}^{2+}\end{array}$ & $\begin{array}{c}\mathrm{K} \\
-----\left(\mathrm{mg} \mathrm{dm}^{-3}\right)---\end{array}$ & $\begin{array}{c}\mathrm{SOM} \\
\left(\mathrm{g} \mathrm{kg}^{-1}\right)\end{array}$ \\
\hline 6 years & 6.1 & 0.1 & 2.5 & 0.9 & 30.5 & 2.3 & 35.2 \\
10 years & 5.8 & 0.1 & 2.8 & 1.2 & 40.8 & 3.1 & 35.2 \\
13 years & 6.3 & 0.1 & 3.4 & 1.3 & 111.4 & 3.9 & 41.1 \\
TM & 5.0 & 0.8 & 0.1 & 0.2 & 24.9 & 0.4 & 37.2 \\
BM & 5.4 & 0.3 & 0.1 & 0.2 & 19.8 & 0.4 & 39.8 \\
\hline
\end{tabular}

${ }^{(1)}$ Time of conversion: 6,10 , and 13 years. ${ }^{(2)} \mathrm{TM}$, top of the murundus; BM, between the murundus. SOM, soil organic matter. 
centrifugation at $1,720 \mathrm{~g}$ for $15 \mathrm{~min}$. The supernatant protein was quantitated in mass spectrophotometer by the Bradford reagent assay, using bovine serum albumin as a standard (Wright \& Upadhyaya, 1998). Total soil mycelium (TSM) was extracted by flotation in $45 \%$ sucrose, filtered on a gridded membrane, and stained with trypan blue, to enhance viewing in microscope, for quantification as described in Melloni \& Cardoso (1999). Total organic carbon (TOC) in soil was determined by oxidation of potassium dichromate and titration with $0.05 \mathrm{~mol} \mathrm{~L}^{-1}$ ferrous ammonium sulfate (Claessen, 1997). Aggregate stability was determined via moist to obtain the geometric mean diameter (GMD) of the aggregates, according to Kemper \& Chepil (1965).

Data were subjected to analysis of variance, and means were compared by the Scott \& Knott test, at $5 \%$ probability, and by Pearson's correlation using the statistical software Sisvar (Ferreira, 2011).

\section{Results and Discussion}

The community of AMF recorded in fields of murundus and in areas converted to agriculture presented 21 species belonging to 5 families and 3 orders (Table 2). However, positions in order and family taxon of six AMF species are still uncertain (Schuessler, 2013). The AMF species of widespread occurrence in all studied areas were: Ambispora leptoticha, Acaulospora scrobiculata, Gigaspora sp., Dentiscutata scutata, and Glomus macrocarpum. The species Acaulospora cavernata, Acaulospora laevis, Scutellospora reticulata, and Rhizophagus clarus were recovered only from areas with native vegetation (field of murundus), and the species Acaulospora denticulata, Acaulospora rehmii, Acaulospora tuberculata, Scutellospora sp., and Funneliformis badium occurred only in areas converted to agriculture.

The spore diversity of AMF observed in the present study was high, as in Assis et al. (2014), who found 27 AMF species, of which 16 AMF species were similar to the ones identified in the present study. The obtained results are in accordance with those reported by Carvalho et al. (2012), in Cerrado-field areas in Serra do Cipó, in the state of Minas Gerais, Brazil, which was considered a hotspot of AMF diversity by the authors, with 23 AMF species.
Species richness in macroaggregates was similar in all studied areas, ranging from six to eight AMF species (Table 2). However, the area with 6 years of conversion presented 10 species in mesoaggregates and 12 in microaggregates. Regarding classes of aggregate size, the species A. cavernata, $S$. reticulata, Scutellospora sp., and Glomus sp. were recovered only in the macroor mesoaggregates. The species A. laevis, A. rehmii, A. tuberculata, F. badium, and $R$. clarus were recovered only in meso- and microaggregates. Generalist species, recovered in three size classes of aggregates, were also identified, including Ambispora leptoticha, Acaulospora foveata, Acaulospora mellea, A. scrobiculata, Gigaspora sp.,D. scutata, G. macrocarpum, G.tortuosum, and Sclerocystis clavispora.

Arbuscular mycorrhizal fungi diversity has been little studied in different size classes of soil aggregates. The results obtained in the present study are indicative that the species A. laevis, A. rehmii, A. tuberculata, $F$. badium, and $R$. clarus are associated to soil microhabitats related to meso- and microaggregates. Some mycorrhizal fungi may prefer more protected microhabitats for spore production, as is the case of $G$. aggregatum, whose spores may be found within other dead AMF spores, seeds, pollen sacks, and insect exoskeletons (Huang \& Tang, 1988).

The higher species richness of AMF spores in meso- and microaggregates in the area with 6 years may suggest that the impact of the recent conversion to agriculture - with stump removal, land leveling, plowing, and subsoiling - still influences the soil aggregation process and, consequently, the AMF community. These results are indicative that there is greater physical protection of AMF spores to predators, such as nematodes (Zhang et al., 2013), in meso- and microaggregates than in macroaggregates; in contrast, the greatest amount of mycelium and production of glomalin favor the stabilization of these microaggregates (Wright \& Upadhyaya, 1998; Rillig $\&$ Mummey, 2006; Vilela et al., 2014).

The occurrence of the species A. leptoticha, A. scrobiculata, Gigaspora sp., D. scutata, and G. macrocarpum corroborates other studies conducted in the same biome (Carvalho et al., 2012; Ferreira et al., 2012). The species recovered only in areas of native vegetation (A. cavernata, A. laevis, $S$. reticulata, and $R$. clarus) may be adapted to very low fertility soils with $\mathrm{pH}$ below 5.4, concentrations of $\mathrm{Al}^{3+}$ above 
$0.3 \mathrm{cmol}_{\mathrm{c}} \mathrm{dm}^{-3}, \mathrm{Ca}^{2+}+\mathrm{Mg}^{2+}$ around $0.3 \mathrm{cmol}_{\mathrm{c}} \mathrm{dm}^{-3}$, and $\mathrm{P}$ around $0.4 \mathrm{mg} \mathrm{dm}^{-3}$ (Table 1). The species that occurred only in agricultural areas (A. denticulata, A. rehmii, A. tuberculata, Scutellospora sp., and $F$. badium) suggest adaptation to soils corrected with limestone and agricultural gypsum, with $\mathrm{pH}$ above 5.8, concentrations of $\mathrm{Al}^{3+}$ around $0.1 \mathrm{cmol}_{\mathrm{c}} \mathrm{dm}^{-3}$, $\mathrm{Ca}^{2+}+\mathrm{Mg}^{2+} \mathrm{cmol}_{\mathrm{c}}$ above $3.4 \mathrm{dm}^{-3}$, and $\mathrm{P}$ between 2.3 and $3.9 \mathrm{mg} \mathrm{dm}^{-3}$. Some species of fungi respond specifically to the intensity of land use, cultural practices, and soil type, which suggests that these AMF species are a highly suitable bioindicator of soil properties and of the intensity of agricultural land use (Oehl et al., 2011).

Analysis of variance showed interaction among the different studied areas and classes of soil aggregates for the variables spore density of AMF, total glomalin, TOC, and total extraradical mycelium (TEM). The average spore density ranged from 29-606 spores in $50 \mathrm{~mL}$ of soil, and the areas with 13 years of conversion and at the top of the murundus showed the lowest spore density (Table 3). Within the microand macroaggregates, the area with 6 years showed higher spore density than the areas with 10 years and between the murundus. In mesoaggregates, there was no difference between the studied areas and spore density. Spore density was higher in micro- and macroaggregates, but was lower in mesoaggregates; these results are similar to those obtained by Vilela et al. (2014) in a Cerrado Oxisol. The area with 13 years of conversion showed results close to those of the areas between and at the top of the murundus, with a higher

Table 2. Recorded species and frequency of occurrence of mycorrhizal fungi in different classes of soil aggregates from fields of murundus (mounds of soil) converted ${ }^{(1)}$ and not converted (TM and BM) $)^{(2)}$ to agriculture in the Cerrado biome, Brazil.

\begin{tabular}{|c|c|c|c|c|c|c|c|c|c|c|c|c|c|c|c|}
\hline \multirow[t]{2}{*}{ Species $^{(3)}$} & \multicolumn{5}{|c|}{ Macroaggregates } & \multicolumn{5}{|c|}{ Mesoaggregates } & \multicolumn{5}{|c|}{ Microaggregates } \\
\hline & 6 & 10 & 13 & TM & $\mathrm{BM}$ & 6 & 10 & 13 & $\mathrm{TM}$ & $\mathrm{BM}$ & 6 & 10 & 13 & $\mathrm{TM}$ & $\mathrm{BM}$ \\
\hline \multicolumn{16}{|l|}{ Archaeosporales/Ambisporaceae } \\
\hline Ambispora leptoticha & 2 & 1 & 1 & 1 & 1 & 2 & - & - & 2 & 2 & 2 & 2 & - & 1 & 2 \\
\hline \multicolumn{16}{|l|}{ Diversisporales/Acaulosporaceae } \\
\hline Acaulospora cavernata & - & - & - & - & - & - & - & - & 1 & - & - & - & - & - & - \\
\hline Acaulospora denticulata & 1 & - & - & - & - & - & - & - & - & - & 1 & - & - & - & - \\
\hline Acaulospora foveata & 2 & - & 1 & - & - & 1 & - & - & - & - & 1 & 1 & 1 & 1 & - \\
\hline Acaulospora laevis & - & - & - & - & - & - & - & - & - & - & - & - & - & 1 & 1 \\
\hline Acaulospora mellea & - & 1 & 2 & - & 2 & - & 2 & 2 & - & - & 1 & 1 & 2 & - & 1 \\
\hline Acaulospora rehmii & - & - & - & - & - & 1 & 1 & - & - & - & 1 & 1 & - & - & - \\
\hline Acaulospora scrobiculata & 5 & 4 & 4 & - & 2 & 4 & 3 & 2 & 1 & 1 & 5 & 5 & 4 & 2 & 1 \\
\hline Acaulospora tuberculata & - & - & - & - & - & - & - & - & - & - & 1 & 1 & - & - & - \\
\hline \multicolumn{16}{|l|}{ Diversisporales/Gigasporaceae } \\
\hline Dentiscutata heterogama & - & - & 3 & - & 1 & - & - & - & - & - & - & - & 3 & 1 & - \\
\hline Gigaspora sp. & - & 1 & - & 2 & 1 & 1 & - & 1 & 2 & 1 & 1 & - & - & - & - \\
\hline Scutellospora reticulata & - & - & - & - & 2 & - & - & - & - & 1 & - & - & - & - & - \\
\hline Dentiscutata scutata & 1 & 5 & 5 & 5 & 4 & 2 & 3 & 3 & 5 & 5 & 1 & 1 & 2 & 3 & 5 \\
\hline Scutellospora sp. & - & - & - & - & - & 1 & - & 2 & - & - & - & - & - & - & - \\
\hline \multicolumn{16}{|l|}{ Glomerales/Claroideoglomeraceae } \\
\hline Claroideoglomus etunicatum & 2 & - & - & - & - & 4 & - & - & - & - & 3 & - & - & - & 1 \\
\hline \multicolumn{16}{|l|}{ Glomerales/Glomeraceae } \\
\hline Funneliformis badium & - & - & - & - & - & 1 & - & - & - & - & 1 & - & - & - & - \\
\hline Glomus macrocarpum & 4 & 4 & 4 & 4 & 4 & 4 & 4 & 4 & 4 & 5 & 3 & 5 & 4 & 5 & 5 \\
\hline Glomus tortuosum & - & 1 & - & - & - & - & 1 & - & - & 1 & - & 1 & - & 1 & - \\
\hline Glomus sp. & 1 & - & - & 1 & - & - & - & - & - & - & - & - & - & - & - \\
\hline Rhizophagus clarus & - & - & - & - & - & - & - & - & - & - & - & - & - & - & 1 \\
\hline Sclerocystis clavispora & - & 1 & - & 2 & - & - & 2 & - & - & - & - & - & - & 2 & - \\
\hline Species richness & 8 & 8 & 7 & 6 & 8 & 10 & 7 & 6 & 6 & 7 & 12 & 8 & 6 & 9 & 8 \\
\hline
\end{tabular}


number of spores in microaggregates and a similar one in meso- and macroaggregates.

The fact that the areas most recently exposed to soil disturbance (area of 6 and 10 years of conversion) have higher spore density in micro- and macroaggregates shows the impact of agriculture on the AMF community (Zangaro et al., 2013), which was not observed in the preserved areas (between and at the top of the murundus) and in the area with 13 years.

The highest values of TOC and GMD indicate improvements in soil quality. However, the significant negative correlation between spore density and TOC $(\mathrm{r}=-0.73 * *)$ and GMD $(\mathrm{r}=-0.81 * *)$ shows that the environment is not in balance, as observed in the areas with 6 and 10 years of conversion. The area between the murundus presented intermediate spore density due to stress caused by flooding, which, even temporarily, affects the sporulation of AMF. The areas that have lower spore densities of AMF - 13 years of conversion and at the top of the murundus - are probably the most stable and balanced environments for the AMF community. This indicates that after 13 years of conversion to agriculture (tillage system), the area can be stable again for the AMF community. It is important to note that, despite the similar reduction in spore number and richness of AMF, at the top of the murundus and in the area with 13 years of conversion, there was no change in the AMF community. Oehl et al. (2009) studied the dynamics of AMF sporulation in microcosms of different agroecosystems and found that spore density was lower and the AMF community more diverse in conservationist production systems, when compared to intensively managed pastures or even monoculture agriculture. The authors attribute this succession of species within each agroecosystem to the seasonality of sporulation, which is in accordance with the results obtained in the present study.

Studies suggest that when the environment is stressful for the plant, the AMF community is directed to the species' perpetuation mechanism, for example, spore production. Sporulation can be induced by moderate water stress (Kaushal, 2002); moderate grazing (Ba et al., 2012); $\mathrm{pH}$ at the limit; high and low temperature, or high-temperature limit (Costa et al., 2013); and high levels of aluminum (Seguel et al., 2012). In these stressful situations, highly-sporulating AMF species can dominate the unbalanced community, and these species of higher spore-production capacity dominate the AMF community. With time, the tillage system promotes the reduction in the amount of AMF spores, showing that the environment is becoming balanced.

The microaggregates, in all areas, have a greater number of spores than the other classes (Table 3), which may be explained by the increased sporulation of AMF inside the microaggregates, especially of species with small spores and abundant sporulation. This may be associated to the fact that some species were identified only in the soil microaggregates, such as $A$. laevis, A. tuberculata, and $R$. clarus, and that AMF richness was higher in microaggregates, with no major differences observed among the studied areas.

The content of total glomalin was higher in the area between the murundus than in the other studied areas, and only areas without human intervention showed higher content in macro- and mesoaggregates (Table 3). TOC in macroaggregates was higher in the area between the murundus, differing from the other evaluated areas. In mesoaggregates, significant differences were observed between the studied areas, whereas microaggregates at the top of the murundus, between the murundus, and at

Table 3. Spore density, total glomalin, total organic carbon (TOC), and total extraradical mycelium (TEM) in different classes of soil aggregates (macro-, meso-, and microaggregates) in fields of murundus (mounds of soil) converted and not converted (TM and BM) to agriculture in the Cerrado biome, Brazil ${ }^{(1)}$.

\begin{tabular}{|c|c|c|c|c|c|c|c|c|c|c|c|c|}
\hline \multirow[t]{3}{*}{ Areas } & \multicolumn{3}{|c|}{ Spore density } & \multicolumn{3}{|c|}{ Total glomalin } & \multicolumn{3}{|c|}{ Total organic carbon } & \multicolumn{3}{|c|}{ Total extraradical mycelium } \\
\hline & Macro & Meso & Micro & Macro & Meso & Micro & Macro & Meso & Micro & Macro & Meso & Micro \\
\hline & \multicolumn{3}{|c|}{---(№ of spores per $\left.50 \mathrm{~mL}^{-1}\right)---$} & \multicolumn{3}{|c|}{------------(mg g-1 soil)-------------- } & \multicolumn{3}{|c|}{ 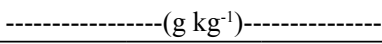 } & \multicolumn{3}{|c|}{ 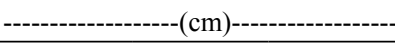 } \\
\hline 6 years & $152 \mathrm{aB}$ & $74 \mathrm{aC}$ & $606 \mathrm{aA}$ & $5.5 \mathrm{bA}$ & $3.1 \mathrm{cA}$ & $3.2 \mathrm{bA}$ & $8.6 \mathrm{dA}$ & $10.5 \mathrm{aA}$ & $10.1 \mathrm{bA}$ & $90.8 \mathrm{bB}$ & $90.0 \mathrm{bB}$ & $106.2 \mathrm{bA}$ \\
\hline 10 years & $135 \mathrm{aB}$ & $58 \mathrm{aC}$ & $292 \mathrm{bA}$ & $2.4 \mathrm{cA}$ & $3.3 \mathrm{cA}$ & $3.3 \mathrm{bA}$ & $13.1 \mathrm{bA}$ & $13.2 \mathrm{aA}$ & $9.8 \mathrm{bB}$ & $51.7 \mathrm{~dB}$ & $64.9 \mathrm{~dB}$ & $83.5 \mathrm{cA}$ \\
\hline 13 years & $43 \mathrm{bB}$ & $21 \mathrm{aB}$ & $131 \mathrm{dA}$ & $3.5 \mathrm{bA}$ & $2.6 \mathrm{cA}$ & $2.6 \mathrm{bA}$ & $11.6 \mathrm{cA}$ & $11.0 \mathrm{aA}$ & $13.5 \mathrm{aA}$ & $47.7 \mathrm{dA}$ & $47.6 \mathrm{dA}$ & $66.3 \mathrm{cA}$ \\
\hline $\mathrm{TM}$ & $34 \mathrm{bB}$ & $29 \mathrm{aB}$ & $98 \mathrm{dA}$ & $2.3 \mathrm{cB}$ & $4.6 \mathrm{bA}$ & $3.3 \mathrm{bB}$ & $11.1 \mathrm{cB}$ & $12.9 \mathrm{aA}$ & $14.4 \mathrm{aA}$ & $105.0 \mathrm{aA}$ & $105.0 \mathrm{aA}$ & $135.9 \mathrm{aA}$ \\
\hline BM & $91 \mathrm{aB}$ & $69 \mathrm{aB}$ & $226 \mathrm{cA}$ & $6.8 \mathrm{aA}$ & $6.5 \mathrm{aA}$ & $5.2 \mathrm{aB}$ & $15.8 \mathrm{aA}$ & $12.1 \mathrm{aB}$ & $12.1 \mathrm{aB}$ & $77.7 \mathrm{cB}$ & $77.7 \mathrm{cB}$ & $114.3 \mathrm{bA}$ \\
\hline
\end{tabular}

${ }^{(1)}$ Means followed by equal letters, uppercase in the lines and lowercase in the columns, do not differ by the Scott \& Knott test, at $5 \%$ probability. Time of conversion: 6, 10, and 13 years. TM, top of the murundus; BM, between the murundus. 
the area with 13 years of conversion presented higher TOC values than the other areas of 6 and 10 years.

In the area at the top of the murundus, in all evaluated classes of aggregates, higher TEM values were found in relation to the other studied areas, and the areas with 10 and 13 years of conversion had lower lengths of TEM in all classes of aggregates (Table 3). The microaggregates showed greater length of TEM, except for the areas with 13 years and at the top of the murundus.

The concentration of total glomalin was not influenced by time of adoption of the tillage system (Table 3), and tended to be similar to that at the top of the murundus, depending on the class of aggregates, which suggests that glomalin did not effectively distinguish agricultural areas. The highest content of glomalin was found between the murundus in all classes of aggregates, confirming that areas with flooding problems have higher levels of this glycoprotein, as verified by Maček et al. (2012). These authors found that, in soils with poor oxygenation, root colonization by AMF is present and glomalin levels are higher, possibly because of the slow decomposition of this glycoprotein in soils with hypoxia.

The similar levels of TOC in microaggregates between areas of natural vegetation (top of and between the murundus) and the area with 13 years of conversion indicate improvements in this attribute due to the employed management, providing stabilization of TOC in the studied soil. Macroaggregate TOC contents were lower in the late-revolved agricultural area (6 years of conversion), which suggests further consequence of the conversion into agricultural area. The negative correlation of spore density $\left(\mathrm{r}=-0.73^{* *}\right)$ and the full positive correlation of mycelium $\left(\mathrm{r}=0.57^{*}\right)$ and glomalin $\left(\mathrm{r}=0.65^{*}\right)$ with organic carbon confirm the importance of AMF for the maintenance of soil organic carbon.

TEM decreased with conversion time of the fields of murundus into agricultural areas. This may be due to increased soil fertility, since it reduces colonization and, therefore, extraradical mycelium (Dai et al., 2013). In relation to the classes of aggregates, TEM was greater in microaggregates, confirming that this class of aggregates has the highest spore density of AMF and that there is a positive correlation between TEM and the content of total glomalin $\left(r=0.88^{* *}\right)$.
GMD presented significant increase with the time of tillage (Figure 1). The results of the present study are indicative that the used management promoted improvements in soil structure, and, consequently, in soil quality, which corroborates other studies (Bedini et al., 2009; Peng et al., 2013). The positive and significant correlation between GMD and the content of total glomalin $\left(\mathrm{r}=0.84^{* *}\right)$, TOC $\left(\mathrm{r}=0.76^{* *}\right)$, and TEM $\left(r=0.51^{*}\right)$ suggest that these factors interact to stable aggregate formation in water, which is essential for environments less susceptible to wide fluctuations in temperature and humidity and, therefore, less stressful to plants and mycorrhizal fungi. This is evidenced by the negative correlation between GMD and spores $\left(\mathrm{r}=-0.81^{* *}\right)$, indicating that in the areas of lower soil structural stability, greater sporulation occurs, improving the survival of the fungus.

The studied soil showed a high spore diversity of AMF, as observed in Assis et al. (2014). It has been found that a community of AMF occupies different habitats regarding classes of aggregates and agricultural and natural systems, but there are always species present in varying general conditions. Possibly, these AMF species are responsible for maintaining the resilience of soil impacts after conversion, whereas the AMF species that occupy specific microhabitats are good

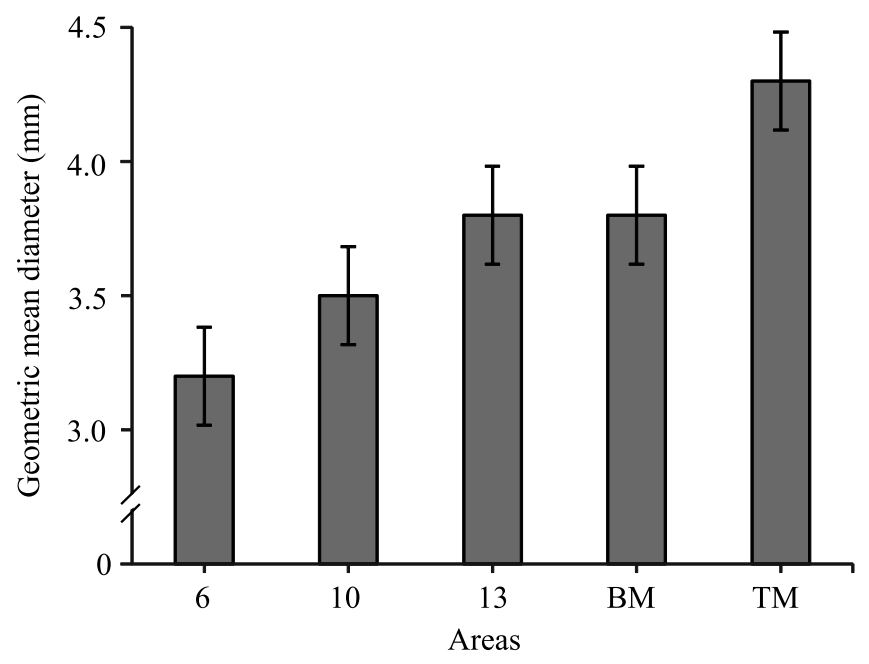

Figure 1. Geometric mean diameter of the soil aggregates from fields of murundus (mounds of soil) converted (time of conversion of 6,10 , and 13 years) and not converted (TM and BM) to agriculture in the Cerrado biome, Brazil. Bars represent the DMS, at 5\% probability. TM, top of the murundus; BM, between the murundus. 
indicators of soil quality. In addition, soil structure, assessed in the present study by GMD, was severely affected when fields of murundus were converted to agriculture and its recovery was slow - even after 13 years, its values were still not similar to those of the uncultivated area, at the top of the murundus.

\section{Conclusions}

1. The density and diversity of arbuscular mycorrhizal spores change with the conversion of fields of murundus into agriculture.

2. The higher density and diversity of arbuscular mycorrhizal spores are found in soil meso- and microaggregates in areas with 6 and 10 years of conversion to agriculture.

3. The species Acaulospora cavernata, Scutellospora reticulata, Scutellospora sp., and Glomus sp. are only present in macro- and mesoaggregates, whereas the species Acaulospora laevis and Rhizophagus clarus are only found in microaggregates.

4. The soil structure of fields of murundus is affected when converted to agriculture and its recovery is slow.

\section{Acknowledgments}

To Conselho Nacional de Desenvolvimento Científico e Tecnológico (CNPq), for financial support (Process no 559682/2009-3 and 308207/2011-4); to Coordenação Nacional de Aperfeiçoamento de Pessoal de Nível Superior (Capes), for the research grant to the second author; to the owner of Fazenda Boa Vista, Nayde Carvalho, for logistical support; to Universidade Federal de Goiás, Regional Jataí; and to Embrapa Agrobiologia, for training opportunity and laboratorial infrastructure to carry out this experiment.

\section{References}

ASSIS, P.C.R.; SAGGIN JÚNIOR, O.J.; PAULINO, H.B.; STÜRMER, S.L.; SIQUEIRA, J.O.; CARNEIRO, M.A.C. Fungos micorrízicos arbusculares em campos de murundus após a conversão para sistemas agrícolas no Cerrado. Revista Brasileira de Ciência do Solo, v.38, p.1703-1711, 2014. DOI: 10.1590/ S0100-06832014000600005.

BA, L.; NING, J.; WANG, D.; FACELLI, E.; FACELLI, J.M.; YANG, Y.; ZHANG, L. The relationship between the diversity of arbuscular mycorrhizal fungi and grazing in a meadow steppe. Plant and Soil, v.352, p.143-156, 2012. DOI: 10.1007/ s11104-011-0985-6.
BEDINI, S.; PELlEGRINO, E.; AVIO, L.; PELLEGRINI, S.; BAZZOFFI, P.; ARGESE, E.; GIOVANNETTI, M. Changes in soil aggregation and glomalin-related soil protein content as affected by the arbuscular mycorrhizal fungal species Glomus mosseae and Glomus intraradices. Soil Biology and Biochemistry, v.41, p.1491-1496, 2009. DOI: 10.1016/j.soilbio.2009.04.005.

BUSCOT, F.; VARMA, A. (Ed.). Microorganisms in soils: roles in genesis and functions. Berlin: Springer-Verlag, 2005. 419p. (Soil biology, 3). DOI: 10.1007/b137872.

CARVALHO, F. de; SOUZA, F.A. de; CARRENHO, R.; MOREIRA, F.M. de S.; JESUS, E. da C.; FERNANDES, G.W. The mosaic of habitats in the high-altitude Brazilian rupestrian fields is a hotspot for arbuscular mycorrhizal fungi. Applied Soil Ecology, v.52, p.9-19, 2012. DOI: 10.1016/j.apsoil.2011.10.001.

CAVAGNARO, T.R.; JACKSON, L.E.; SIX, J.; FERRIS, H.; GOYAL, S.; ASAMI, D.; SCOW, K.M. Arbuscular mycorrhizas, microbial communities, nutrient availability, and soil aggregates in organic tomato production. Plant and Soil, v.282, p.209-225, 2006. DOI 10.1007/s11104-005-5847-7.

CLAESSEN, M.E.C. (Org.). Manual de métodos de análise de solo. 2.ed. Rio de Janeiro: EMBRAPA-CNPS, 1997. 212p. (EMBRAPA-CNPS. Documentos, 1).

COSTA, F.A.; HADDAD, L.S.M.; KASUYA, M.C.M.; OTON, W.C.; COSTA, M.D.; BORGES, A.C. In vitro culture of Gigaspora decipiens and Glomus clarum in transformed roots of carrot: the influence of temperature and $\mathrm{pH}$. Acta Scientiarum. Agronomy, v.35, p.315-323, 2013. DOI: 10.4025/actasciagron.v35i3.16581.

DAI, J.; HU, J.; LIN, X.; YANG, A.; WANG, R.; ZHANG, J.; WONG, M.H. Arbuscular mycorrhizal fungal diversity, external mycelium length, and glomalin-related soil protein content in response to long-term fertilizer management. Journal of Soils and Sediments, v.13, p.1-11, 2013. DOI: 10.1007/s11368-012-0576-z.

FERREIRA, D.A.; CARNEIRO, M.A.C.; SAGGIN JUNIOR, O.J. Fungos micorrízicos arbusculares em um Latossolo Vermelho sob manejos e usos no Cerrado. Revista Brasileira de Ciência do Solo, v.36, p.51-61, 2012. DOI: 10.1590/S0100-06832012000100006.

FERREIRA, D.F. Sisvar: a computer statistical analysis system. Ciência e Agrotecnologia, v.35, p.1039-1042, 2011. DOI: 10.1590/S1413-70542011000600001.

GERDEMANN, J.W.; NICOLSON, T.H. Spores of mycorrhizal Endogone species extracted from soil by wet sieving and decanting. Transactions of the British Mycological Society, v.46, p.235-244, 1963. DOI: 10.1016/S0007-1536(63)80079-0.

HUANG, R.S.; TANG, C.S. Production of vesicular-arbuscular mycorrhizal sporocarps, Glomus aggregatum, on fiberglass screens. Plant and Soil, v.108, p.233-235, 1988. DOI: 10.1007/ BF02375653.

KAUSHAL, S. Factors affecting spore population and root colonization in Prosopis cineraria. Advances in Plant Sciences, v.15, p.327-330, 2002.

KEMPER, W.D.; CHEPIL, W.S. Size distribution of aggregates. In: BLACK, C.A. (Ed.). Methods of soil analysis. Part 1. Physical and mineralogical properties, including statistics of measurement and sampling. Madison: American Society of 
Agronomy, 1965. p.499-510. (ASA. Agronomy, 9). DOI: 10.2134/ agronmonogr9.1.c39.

KLIRONOMOS, J.N.; ALLEN, M.F.; RILLIG, M.C.; PIOTROWSKI, J.; MAKVANDI-NEJAD, S.; WOLFE, B.E.; POWELL, J.R. Abrupt rise in atmospheric $\mathrm{CO}_{2}$ overestimates community response in a model plant-soil system. Nature, v.433, p.621-624, 2005. DOI: 10.1038/nature03268.

MAČEK, I.; KASTELEC, D.; VODNIK, D. Root colonization with arbuscular mycorrhizal fungi and glomalin-related soil protein (GRSP) concentration in hypoxic soils in natural $\mathrm{CO}_{2}$ springs. Agricultural and Food Science, v.21, p.62-71, 2012.

MARIMON, B.S.; MARIMON-JUNIOR, B.H.; MEWS, H.A.; JANCOSKI, H.S.; FRANCZAK, D.D.; LIMA, H.S.; LENZA, E.; ROSSETE, A.N.; MORESCO, M.C. Florística dos campos de murundus do Pantanal do Araguaia, Mato Grosso, Brasil. Acta Botanica Brasilica, v.26, p.181-196, 2012. DOI: 10.1590/ S0102-33062012000100018.

MELLONI, R.; CARDOSO, E.J.B.N. Quantificação de micélio extrarradicular de fungos micorrízicos arbusculares em plantas cítricas e endófitos. I. Método empregado. Revista Brasileira de Ciencia do Solo, v.23, p.53-58, 1999. DOI: 10.1590/ S0100-06831999000100007.

MILLER, R.M.; JASTROW, J.D. Mycorrhizal fungi influence soil structure. In: KAPULNIK, Y.; DOUDS JR, D.D. (Ed.). Arbuscular mycorrhizas: physiology and function. Dordrecht: Kluwer Academic Publishers, 2000. p.3-18. DOI: 10.1007/978-94-017-0776-3_1.

OEHL, F.; JANSA, J.; INEICHEN, K.; MÄDER, P.; VAN DER HEIJDEN, M. Arbuscular mycorrhizal fungi as bio-indicators in Swiss agricultural soils. Recherche Agronomique Suisse, v.2, p.304-311, 2011.

OEHL, F.; SIEVERDING, E.; INEICHEN, K.; MÄDER, P.; WIEMKEN, A.; BOLLER, T. Distinct sporulation dynamics of arbuscular mycorrhizal fungal communities from different agroecosystems in long-term microcosms. Agriculture, Ecosystems and Environment, v.134, p.257-268, 2009. DOI: 10.1016/j.agee.2009.07.008.

PENG, S.; GUO, T.; LIU, G. The effects of arbuscular mycorrhizal hyphal networks on soil aggregations of purple soil in southwest China. Soil Biology and Biochemistry, v.57, p.411-417, 2013. DOI: $10.1016 /$ j.soilbio.2012.10.026.

RAHLAO, S.J.; HOFFMAN, M.T.; TODD, S.W.; McGRATH, K. Long-term vegetation change in the Succulent Karoo, South Africa following 67 years of rest from grazing. Journal of Arid Environments, v.72, p.808-819, 2008. DOI: 10.1016/j. jaridenv.2007.08.003.
RILLIG, M.C.; MUMMEY, D.L. Mycorrhizas and soil structure. New Phytologist, v.171, p.41-53, 2006. DOI: 10.1111/j.1469-813 7.2006.01750.x.

SANTOS, H.G. dos; JACOMINE, P.K.T.; ANJOS, L.H.C. dos; OLIVEIRA, V.A. de; OLIVEIRA, J.B. de; COELHO, M.R.; LUMBRERAS, J.F.; CUNHA, T.J.F. (Ed.). Sistema brasileiro de classificação de solos. 2.ed. Rio de Janeiro: Embrapa Solos, 2006. $306 \mathrm{p}$.

SCHUESSLER, A. Phylogeny and taxonomy of Glomeromycota ('arbuscular mycorrhizal (AM) and related fungi'). 2013. Available at: <http://schuessler.userweb.mwn.de/amphylo/>. Accessed on: 21 abr. 2014.

SEGUEL, A.; MEDINA, J.; RUBIO, R.; CORNEJO, P.; BORIE, F. Effects of soil aluminum on early arbuscular mycorrhizal colonization of wheat and barley cultivars growing in an Andisol. Chilean Journal of Agricultural Research, v.72, p.449-455, 2012. DOI: $10.4067 / \mathrm{S} 0718-58392012000300022$.

SILVA, L.C.R.; VALE, G.D.; HAIDAR, R.F.; STERNBERG, L. da S.L. Deciphering earth mound origins in central Brazil. Plant and Soil, v.336, p.3-14, 2010. DOI: 10.1007/s11104-010-0329-y.

TISDALL, J.M.; OADES, J.M. Organic matter and water-stable aggregates in soils. Journal of Soil Science, v.33, p.141-163, 1982. DOI: 10.1111/j.1365-2389.1982.tb01755.x.

TISDALL, J.M.; SMITH, S.E.; RENGASAMY, P. Aggregation of soil by fungal hyphae. Australian Journal of Soil Research, v.35, p.55-60, 1997. DOI: 10.1071/S96065.

VILELA, L.A.F.; SAGGIN JÚNIOR, O.J.; PAULINO, H.B.; SIQUEIRA, J.O.; SANTOS, V.L. da S.; CARNEIRO, M.A.C. Arbuscularmycorrhizal fungus in microbial activity and Aggregation of a Cerrado Oxisol in crop sequence. Ciência e Agrotecnologia, v.38, p.34-42, 2014. DOI: 10.1590/S1413-70542014000100004.

WRIGHT, S.F.; UPADHYAYA, A. A survey of soils for aggregate stability and glomalin, a glycoprotein produced by hyphae of arbuscular mycorrhizal fungi. Plant and Soil, v.198, p.97-107, 1998. DOI: 10.1023/A:1004347701584.

ZANGARO, W.; ROSTIROLA, L.V.; SOUZA, P.B. de; ALVES, R. de A.; LESCANO, L.E.A.M.; RONDINA, A.B.L.; NOGUEIRA, M.A.; CARRENHO, R. Root colonization and spore abundance of arbuscular mycorrhizal fungi in distinct successional stages from an Atlantic rainforest biome in southern Brazil. Mycorrhiza, v.23, p.221-233, 2013. DOI: 10.1007/s00572-012-0464-9.

ZHANG, S.; LI, Q.; YING, L.; ZHANG, X.; LIANG, W. Contributions of soil biota to $\mathrm{C}$ sequestration varied with aggregate fractions under different tillage systems. Soil Biology and Biochemistry, v.62, p.147-156, 2013. DOI: $10.1016 / \mathrm{j}$. soilbio.2013.03.023.

Received on April 25, 2014 and accepted on March 11, 2015 